\title{
Principals' Perceptions of Independence Mission Schools in the Catholic Archdiocese of Philadelphia
}

\author{
Linus D. Nangwele, Ph.D. ${ }^{*}$ and Bandlow Raymond, Ph.D. ${ }^{2}$ \\ 1. 2. School of Graduate and Professional Studies, Gwynedd Mercy University, Gwynedd Valley, \\ Pennsylvania \\ Emails: nangwele.1@gmercyu.edu *(corresponding author) bandlow.r@gmercyu.edu
}

\begin{abstract}
This study is a contribution to a new model of Catholic education that has emerged in the Catholic Archdiocese of Philadelphia, USA in the past eight years. The primary purpose of the research was to understand the experiences and perceptions of principals of the establishment and 'mission' of Independence Mission Schools (IMS) in the Archdiocese of Philadelphia. The study was approached qualitatively and designed as a case study. Using a sample of nine IMS principals, data was collected through interviews and analyzed thematically. The study found that there is great value for Catholic education. The study also unearthed that the principals of these institutions have deep understanding of the mission and vision of the IMS including the following: That the IMS system provides a model of Catholic education, a viable alternative to other private and public education providers; provides holistic education for the poor, ensures continuity in Catholic education, provides safe, caring, and supportive environment for students. The study further discovered that the Principals adopt different strategies to accomplish the mission and vision of IMS. Additionally, IMS impacts positively on students' lives. However, limited finance, teacher turnovers, operation of schools as businesses have been challenging to the Principals' effective management of the IMS schools. The principals nonetheless have positive perceptions of IMS's future. At the same time, the principals expressed concerns about the sustainability of the IMS network. To ensure the sustainability of the IMS vision and mission, the Principals, during the study, recommended that more financial resources should be obtained, remunerations of teachers should be increased, Catholic identity should be kept in schools, improve competitive advantage, encourage good relationships, and constantly revisit the network's mandate. The study has important implications for stakeholders. Stakeholders can use the findings of the study to meet the critical needs of the IMS network. Since the study was limited to only nine principals, it is recommended that a further research may be carried out to take into account the perceptions of other key actors in the IMS network such as teachers, students, parents and board members. That way a deeper understanding of the establishment mission of the IMS might be gained.
\end{abstract}

Keywords: Principals, Perceptions, Independence Mission Schools, Archdiocese, Philadelphia

DOI: $10.7176 / \mathrm{JEP} / 12-10-11$

Publication date: April $30^{\text {th }} 2021$

\section{Introduction}

Catholic schools are known for their strong educational foundation in the United States since the 1600s. The reality of Catholic schools closing in many dioceses and Archdioceses across the United States of America (USA) in recent years has been heartbreaking for many Catholics who have a strong bond with Catholic faithbased education. In the past decade there has been a decline in enrollment in many Catholic Schools (Bring \& Garnett, 2014). Among other things, one factor that seems to contribute to low enrollment and closure of Catholic schools in USA is the diminished financial standing of many parishes and dioceses (Miserandino, 2019; Goldschmidt \& Walsh, 2011; Hamilton, 2008; De La Portilla, 2018). This crisis has affected many dioceses across the country. One Archdiocese that is most affected by the declining enrollment and closure of Catholic Schools is the Catholic Archdiocese of Philadelphia.

The Archdiocese of Philadelphia has a long-standing history of providing Catholic education to families of all economic and cultural backgrounds (USCCB, 2013). In January 2012, the new Archbishop of Philadelphia, the Most Reverend Charles Chaput, announced that he would close forty-eight Catholic elementary schools at the end of the school year. The closure of forty-four elementary schools and four high schools displaced nearly 24,000 students (Bring \& Garnett, 2014). While heartbreaking for the students, parents, and teachers at the targeted schools, the Archbishop's decision came as no surprise to those familiar with the current landscape of Catholic education (Bring \& Garnett, 2014). "Nationwide, over 1,600 Catholic schools have been closed in the past two decades, displacing more than 300,000 students. The Archdiocese of Philadelphia itself has closed thirty schools in the previous five years, as enrollments plummeted (falling by $35 \%$ since 2001) and costs skyrocketed" (Bring \& Garnett, 2014, p. ix).

The closure of Catholic schools across the city of Philadelphia sparked great upset and disappointment in many devout Catholics and educators who sought to argue that Catholic schools have been around for decades 
and have had a history of educating generations of faithful Catholics and responsible citizens. Many people continue to express 'hurt, anger and sadness' as to why and how schools with such background and history could close; given such a 'simple explanation' of - lack of financial sustainability (De La Portilla, 2018.p. 33). Yet, it appears the trend of school closures continues unabated as more schools and parishes are put on the "threatened list". Tensions are thus appearing in Catholic schooling in contemporary times (Garcia-Huidobro, 2017; O’Connel et al., 2012).

The network of 15 Independence Mission Schools (IMS) was established in 2012 in the lower-income communities across the city of Philadelphia to counteract Archbishop Chaput's attempts to close some parish schools that were financially struggling. Since the establishment of the network, research is deficient in aiding a better understanding of the establishment and mission of IMS. There is no previous scholarly research on the establishment and mission of the network. Yet, no one seems to be interested in seeking a deeper understanding of the establishment and mission of Independent Mission Schools. Additionally, the scanty information about the IMS establishment, which is displayed on the official website, lacks the active voices of the schools' principals who oversee the operations of the schools. As key stakeholders in the IMS establishment, how principals perceive their network could have a decisive effect on how they administer the schools. Herein lies the critical question this research poses: What are the perceptions of principals of IMS of the establishment and mission of the IMS network?

This study is an attempt to close the above gaps and by so doing expand the horizons of knowledge about the IMS establishment and mission in the Archdiocese of Philadelphia. The research contributes to Catholic education literature by exploring the perceptions of the principals in Independence Mission Schools. The study sought answers to the following questions: How do principals understand the mission of the network of Independence Mission Schools? What are principals' experiences of the impact of Independence Mission Schools on the lives of their students? What challenges do principals experience as principals of IMS? What strategies have principals adopted to accomplish the mission of the Independence Mission Schools? What are principals' perceptions of the future of the Independence Mission Schools?

The research was approached qualitatively and designed as a case study. A total of nine principals were purposively sampled and interviewed. The data provided by principals was analyzed thematically.

\section{Literature}

The Catholic Church has contributed significantly to the provision of educational opportunities to many American populations over the past two hundred years (Gleeson, O'Gorman, Goldburg \& O'Neill, 2018). The past two decades witnessed a wave of school closures in many dioceses and Archdioceses in the United States. Enrolment figures began slowing down by the 1990s through to the 2000s (USCCB, 2005; Gleeson et al., 2018). Many believe that good enrollment is a major contributor to a Catholic school's viability along with regular donations. There have been divergent opinions on the reasons for the closure of schools in the Archdiocese of Philadelphia. While some people believed that the Archdiocese of Philadelphia could not keep schools and parishes open because of its financial settlements in the clergy sex abuse scandals (De Fiore, Convey \& Schuttloffel, 2009). others too blame the closures on the economic downturn in recent years (America Association of School Administrators, 2009; Hamilton, 2008; Meyer, 2007). The provision of Catholic education in terms of costs has come to be burdensome and challenging for many parishes and dioceses over the years (Jacobs, 1998; Miserandino, 2019; Goldschmidt \& Walsh, 2011; Agirdag, Driessen \& Merry, 2017). This is threatening the future of Catholic education (Miserandino, 2019). Owing to the trending crisis, many Catholic schools have had to find innovative ways to keep the identity of the Catholic schools alive. One such innovative step was the emergence of the network of 15 schools located in low-income areas across the city of Philadelphia. They bonded together to keep the mission of Catholic education alive in the affected communities. The mission of the network of IMS was to reframe Catholic education (Bolman \& Deal, 2013) by providing an alternative model of leadership in the delivery of Catholic education in the schools that are in poor communities of Philadelphia. Chiefly, "children of low-income, inner-city, and underserved families of all faiths" have access to Independent Mission Schools (Independent Auditor's Report, 2018, p. 5). The curriculum of Independent Mission Schools appears to mirror that of the Catholic school curricula because "mission schools" still offer academic and religious programs consistent with the faith and morals (Catholic Doctrine) as interpreted by the Archdiocese" (Independent Auditor's Report, 2018, p. 5). The Catholic identity is integral in the designing of the Catholic school's curriculum (Garcia-Huidobro, 2017). While promoting high quality Catholic education, Independence Mission Schools develop in students, academic excellence, $21^{\text {st }}$ century skills, among others, and confident that education is the best investment to secure the future of children, and foundational to our living and a flourishing human person (IMS, 2014).

Meanwhile, the clergy sex scandal across the United States caused some parents to lose faith while others became hesitant to leave their children under the supervision of clergymen (Van Wormer \& Berns, 2004). 
Consequently, many Catholic administrators are struggling and under pressure to keep up with the times and thinking outside the box to ensure their place at the top in the current competitive educational environment (Polka, Litchka, Mete \& Ayaga, 2016). According to Goldschmidt and Walsh (2011), "the future of Catholic schools requires that we identify, implement, measure and market models that demonstrate effective governance, financial sustainability, and academic quality" (p. 4). Meyer (2007) believes strongly in schools developing a good marketing plan. Meyer insists that, "Catholic schools will have to become expert fundraisers to survive" (p. 18). Townsley (2014) argued that no educational institution can survive without a sound financial equilibrium. Miserandino (2019) notes that "unless a new approach to funding schools is developed, the future of Catholic education in the United States is seriously threatened and with it the American church" (p. 105). Coday (2005) recommends that Catholic schools should focus on serving the children in poor neighborhoods to receive additional government funding. The times have changed, and according to Cruz (2009) the ways of doing business has changed as well.

Catholic education blends the teaching of the Catholic beliefs and practices with the core academic work; that is "education that is both truly Catholic and of the highest academic quality" (USCCB, 2005, p. 1). Catholic education prepares students for heaven (Hancock, 2005). Borba (2001) argued that a strong character is what children need to be good human beings in life. Catholic education operates a curriculum that is characterized by "academically rigorous and doctrinally sound program of education" (USCCB, 2005, p. 3). The religious affiliation of students in Catholic schools (Gleeson et al., 2018) and demography has changed (Miserandino, 2019; Schuttloffel, 2012). Diversity ensures sustainable schools (Tucker, 2016). Lewin (2007) argues that schools should be 'friendly, welcoming, caring, supportive and nurturing' entities. Fay (2005) argues the need to recognize children's potentials and tap their strengths. Safe environments ensure schools' sustainability (Tucker, 2016). Slate, Jones, Wiesman, Alexander and Saenz (2008) think schools have as part of their mission to create a safe, caring, and nurturing environment.

Catholic schools promote parental engagement, help build a better society, nurture potential, and provide subsidized education (USCCB, 2016). Thus, according to Miserandino (2019), what differentiates Catholic schools from their public counterparts is in Catholic schools' critical attention to the poor and other social Justice programs. That is "a central tenet of faith" and "a distinctive value-added feature" of Catholic schools (Miserandino, 2019, p. 106). The Catholic identity is what sustains schools (Tucker, 2016). The Catholic identity is important in staff formation (Brisbane Catholic Education, 2015). Identity is nurtured (Cook, 2008). Catholic schools contain religion and academic orientation contents (Convey, 2012). Teachers and principals have the obligation to preserve the Catholic identity and to protect and promote the Catholic faith of their students and develop an environment or school climate that is caring, nurturing and supportive for students (Gleeson, 2017; Convey, 2012; Baccari, 2018; Gleeson et al., 2018). Hawley and Rollie (2007) indicate that accountability ensures improvement. Religious knowledge is important in drawing students closer to God and helps them to fit and function well in the Church, country, and the world (Sullins, 2004). Noteworthy, "Catholic schools...should have a distinct Catholic culture" (Convey, 2012, p. 190). The Catholic school is unique and effective in terms of its "sense of community" (Fuller \& Johnson, 2014, p. 98). The saying of prayers, religious teachings, celebration of Mass, discipline, sacraments, Christian activities, presence of crucifixes, religious pictures, statues and others are common with Catholic schools (Convey, 2012; Gleeson et al., 2018; Baccari, 2018; Fuller \& Johnson, 2014; Inglis, 2007). Convey (2012) indicates that Catholic "school's faith community is a functional community that produces social capital and is a major contributor to the effectiveness of the school" (p.190).

\section{FINDINGS AND DISCUSSION}

This section presents and discusses the findings of the study. The presentation and discussion of the findings of the study are based on the themes generated from the transcribed interviews of nine principals of the IMS.

\section{Principals' Understanding of the Mission and Vision of the IMS}

Principals expressed a deep understanding of the mission and vision of the Independence Mission Schools. A model of catholic education

Principals understand IMS as an entity that seeks to provide an education to children that draws them closer to God; education that exposes students to Catholicism and the need to treat and love their neighbors as themselves. Principals indicated that IMS seeks to be a model for Catholic education in the city and the country. Some principals shared in the interview:

...to provide Catholic education for poor children in the poor sections of the city... (Field Data, Respondent 1) 
IMS wants to provide education for the child that is in keeping with the Catholic faith. The network wants to ensure that the Catholic tradition is not lost in schools. Bolman and Deal (2013) affirmed that the goal of IMS is to provide Catholic education in the schools that are in poor communities of Philadelphia. Principals indicate that IMS wants to offer children the chance to experience and to be taught what Catholicism is and how to grow closer to God. Principals understand IMS mission and vision as a network that is championing and preserving Catholic education.

\section{A viable option/alternative}

The Principals also understood the mission and vision of IMS as one that offers a strong alternative. Their understanding is that IMS offers an opportunity for the poor in the acquisition of education, by providing a viable option to other Catholic and public schools in the city and country. For instance, principals indicated:

I think it's just to have the opportunity to Catholic education available to families throughout the inner city of Philadelphia. ... people or families are looking for an alternative for the students. (Field Data,

\section{Respondent 4)}

IMS gives every everyone a choice. Everyone (teachers, parents, community, etc.) who is part of IMS network has made a choice. It is a choice because teachers know that they are probably not going to get paid as much as they could at other places, and that they have bigger class sizes to work with. According to some of the principals, it is a fairer option because the poor and vulnerable families cannot afford education for their children. Therefore, it is argued that the overarching mission of the network of IMS was to reframe (Bolman \& Deal, 2013) Catholic schools by providing an alternative model of leadership in the delivery of Catholic education in the schools that are in poor communities of Philadelphia.

\section{Developing good citizens}

Principals understand IMS mission and vision of the IMS establishment to imply developing students to become good citizens; citizens who are effective, responsible and informed; and citizens who are functional and seek the common good. IMS trains and educate children to fit into the workplace and the ever dynamic and changing society. Some of the Principals, for instance, shared in the interviews:

...working on the moral and social and emotional development of students...and provide a transformative education for students...so the mission is to develop students...but also morally make good citizens. (Field Data, Respondent 5)

Thus, IMS seeks to develop citizens who will know and do the right thing. Principals understand the mission of IMS as educating children for the future. Principals' understanding is that children who graduate from IMS schools will be useful in society. That is, IMS seeks to train students to be better people in life, to be wellbehaved, to do the right things and take responsibility and accountability for their actions.

\section{Providing safe and caring environment for students}

Principals shared that they understand the IMS mission and vision to mean the provision of safe, caring, supportive and welcoming environment for any student regardless of their background. Principals try to keep positive spirit with students, thereby making them happy persons. IMS creates a kind of environment where everyone - teachers, parents, students, and other staff feel loved, cared for, supported, belonged, and listened to in times of need. Lewin (2007) argued that schools that are welcoming and safe, nurture students' potentials. Slate et al. (2008) noted that most schools have in addition to their primary mission, the commitment to create a safe, caring, and nurturing environment. Students are supported academically, socially, and psychologically. Other Principals shared the following:

.... a school like ours ... it's a caring school ... organize school where they're [children] going to be safe

here, we put our life on the line for kids here. (Field Data, Respondent 2)

IMS helps students, parents and even the community. Principals indicated that even though teachers who come to IMS are paid less, most of them still stay because of the happiness they derive from the school environment. Students too stay and graduate; retention is high. There is a sense of family and community in IMS. One does not need to have money before he or she can eat, enjoy, and participate in IMS. There is that sense of sharing, helping, friendliness, compassion, and fellow feeling in IMS.

\section{Providing quality Catholic and holistic education for the poor}

Principals indicated that the establishment of IMS was to ensure that children are afforded the opportunity to access quality Catholic education. Parents always want the best education for their children and IMS provides that kind of education. For instance, principals indicated that: 
...because of [the establishment of IMS] children are able to receive a quality Catholic education. ...we are trying to educate children and educate the whole child spiritually, academically, and socially so it really is like a three-pronged approach you know to help children grow holistically. (Field Data, Respondent 1)

IMS seeks to provide education that is rigorous and holistic; one that develops every aspect of the student. Independent Auditor's Report (2018) stated that IMS gives children in the inner-city who are from underserved families the opportunity to have quality catholic education. IMS does not only develop the child academically but also morally. IMS exposes students to both core academic knowledge and religious knowledge thereby making the child well-baked and rounded in terms of academics and their knowledge of God. Hancock (2005) argued that Catholic education prepares the child for heaven. A strong character is developed in students. Students are taught how to behave well and morally. They are taught to know and do the right thing at all times. The Centre for Catholic School Effectiveness and Centre for Catholic Education (2012) advanced that Catholic education develops the whole child - intellectually, spiritually, socially, physically, psychologically, morally, aesthetically, and religiously. Therefore, as reiterated by Hancock (2005), the "distinctiveness in catholic education is in its ability to educate the whole person" (p. 34). Character building is thus a significant takeaway from the IMS network. Character counts as far as IMS is concerned. Traits such as trustworthiness, respect, responsibility, fairness, caring, tolerance, kindness, and citizenship and then the Catholic identity are imbibed in students and built in the school environment.

\section{Continuity}

Principals shared that IMS seeks to ensure continuity in the provision of education to children that is in keeping with the Catholic doctrine and the messages of Jesus. They expressed that some people from the business community were concerned that the closure of Catholic schools could compromise the continuous provision of Catholic education. IMS sought to continue to keep Catholic schools alive and vibrant in the city. For instance, some principals shared that:

The mission of the Mission schools is to continue with the Catholic education in Philadelphia... (Field Data, Respondent 7)

...I think one thing that is nice is the stability of a network that keeps them going... (Field Data, Respondent 4)

...want to keep Catholic schools open... (Field Data, Respondent 5)

Brian MacElwe wanted to sustain the schools. (Field Data, Respondent 1)

Thus, IMS came in to salvage the Catholic schools that were being closed due to their serious financial and enrollment challenges and to ensure that students are not deprived of the opportunity to continue to experience education in the Catholic tradition. Principals explained that the network did not want a truncation of the over hundred years of Catholic education provision nor some people to be left behind in the provision and enhancement of Catholic education.

\section{Principals' Experiences of the Impact of IMS on the Lives of their Students}

The principals shared positive experiences of the impact IMS has on students' lives. Students who go through IMS education come out transformed.

\section{Develops good citizens and leaders}

Principals indicated that IMS develops students to be good citizens and leaders in the country and the world. Students who go through IMS education come out to be responsible, effective, and good citizens; citizens who seek the common good and uphold and do the right thing. Principals highlighted that their students are able to function well in their communities and civil society. Some principals shared in the interviews:

...this is a great place to help...children and when you're helping children you are helping the future of society and you're going to make changes in society, so I think stakeholders are happy to see children becoming fine young men and women, good citizens... (Field Data, Respondent 1)

According to the principals, students are their greatest assets, and they try to develop them in the best ways they can to be wonderful and good people in life. Students are developed to be good people in the future and agents of positive change in society.

Builds faith and spirituality in students 
Principals also highlighted that their schools build faith and spirituality in students. Independence Mission Schools educate the whole child. IMS provides the kind of education to students that draw them closer to God. IMS helps students to be aware that it is good to worship and pray. Convey (2012) indicated in the 'Catholic identity model' that building of faith is an important element in Catholic schools. A principal indicated that they are:

...really making sure that they [students] go off as young men and young women of God and of faith.... we pray everyday... (Field Data, Respondent 8)

Furthermore, the principals indicated that they talk about faith to their students and provide religious enrichment in their schools. Although charter schools may have a religious piece, principals stressed that they are able to freely talk about faith and Jesus with their students in IMS. The saying of prayers, religious instructions, celebration of Mass, sacraments, Christian activities, are common with Catholic schools (Convey, 2012; Gleeson et al., 2018; Baccari, 2018; Fuller \& Johnson, 2014; Inglis, 2007). Due to the religious piece that children are given in IMS, they are prayerful, and they know more about God and live godly lives. This supports and strengthens the Catholic identity of the schools (Baccari, 2018). For instance, a principal shared in the interview:

The faith development of children is primary. Their only experience of faith is in St. X school and that was told to one of the other sisters by a group of children that she does religious enrichment when she asked where do you learn about God because she was expecting them to say family or grandparents but they said St. X school. The school is the hub for the faith development... (Field Data, Respondent 9)

Catholic education prepares students for heaven (Hancock, 2005). Therefore, students go out knowing that there is more beyond this world.

\section{Students come back}

Principals also shared that IMS impacts students' lives significantly to the extent that students tend to come back to serve their alma mater. Principals stated that most of their students who graduate come back to serve IMS in various capacities including helping others with food, gifts, teaching and the like. Principals indicated that parents who completed their schools when they were still parish schools tend to also bring their children to their schools so that the same blend of academics and religion can be developed in their wards. Thus, contrary to Schuttloffel's (2012) observation of a diminished value for Catholic schooling, this study unearthed a great value for Catholic education. Principals shared:

We had a little boy here, he went to college, and he came to our school, he brought in food and helped us distribute it to the classroom... we see kids starting kindergarten and preschool and move up the grades see them graduate from our school and they come back. They do, it's the kind of school where kids come back (Field Data, Respondent 1)

\section{...we have a lot of graduates that bring their kids back... (Field Data, Respondent 3)}

It is gratifying to see that students who graduate return to their Alma Mater to help out. Students who come back try to share their experiences with teachers and others, and this could motivate other students to aspire to be there too.

\section{Produces academically sound and well-rounded persons}

Principals indicated that IMS produces students who are academically sound and well-rounded and who are able to function and compete effectively in this complex interconnected world. IMS has a huge academic impact on students. Students in IMS are taken through a rigorous curriculum. As such, the student comes out well-rounded, who are able to move through the academic ladder to become responsible global citizens. For example, a principal indicated in the interview:

...it's really been a part of the school culture here to do well academically...our test scores are one of the highest... our kids do really well... (Field Data, Respondent 8)

Noteworthy, "academically rigorous and doctrinally sound program of education" that is proclaimed in a disciplined environment, where faith and culture are combined and presented to students as a whole makes them functional citizens of the Church, the Country and the World (USCCB, 2005, p. 3). According to principals, students graduate and enter the best of high schools and colleges. Independence Mission Schools produce excellent students who are fed into society to effect good changes adding that it is their culture to produce academically well-rounded persons. Schools that proclaim Catholic education are exemplified by excellence in 
every aspect of the school life (Centre for Catholic School Effectiveness \& Centre for Catholic Education, 2012). Thus, IMS (2014) insists that the network develop in students, academic excellence.

\section{An opportunity to education that is affordable}

IMS seeks to provide education to the poor and vulnerable population. The poor who cannot afford the high fees that are charged in other educational establishments are able to educate their children in IMS. According to principals, tuition is subsidized and they get donations, grants and scholarships to support the students. Parents pay fees but at a less rate. They indicated that different scholarships come from the state of Pennsylvania with tax credits to cover the difference. Principals shared:

...families...pay tuition, they do not completely subsidize it, we do get a lot of scholarship money so on average most parents pay about $\$ 200$ a month. Some scholarships come from...I/O STC. It is an educational tax credit from the government. (Field Data, Respondent 3)

...we do it [educate] for less money. (Field Data, Respondent 6)

Another principal explained that:

There is a sliding scale depending on family income and the number of students that are in the school, but the families do pay. (Field Data, Respondent 4)

IMS offer parents a good opportunity to give their children quality and strong Catholic education at a less cost. Thus, what differentiates Catholic schools from their public counterparts is in Catholic schools' critical attention to the poor (Miserandino, 2019).

Gives students a sense of community and family

Principals indicated that there is a caring, loving, friendly and supportive climate within the IMS. There is show of care, love, and support to others. The Catholic school is unique and effective in terms of its "sense of community" (Fuller \& Johnson, 2014, p. 98). USCCB (2016) stated that Catholic schools foster social cohesion. People come to the aid of others in times of need. For instance, principals highlighted in the interview:

Katherine Drexel instilled in this parish and this school a love of children and a desire to educate the poorest of the poor. (Field Data, Respondent 6)

The principals pointed out that students' psychological, behavioral, and social needs are attended to. Fay (2005) argued that "helping children and their families is building a better future." Principals stated that they try to address trauma and help children to work through it. Poverty is not a barrier to a students' access to food and basic needs in IMS network.

\section{Provides strong foundation}

Principals also indicated that students who go through IMS education are given strong foundation upon which they build their academics while grounding and propelling them to move smoothly on their education ladder and to be better citizens. Some principals shared in the interviews that:

...educating our students so that they can go and be better citizens with a global outlook on things... I certainly believe that academics is the most important thing that we offer our children. (Field Data, Respondent 6)

...we are empowering students to obtain a really strong foundation in their math and reading in addition to having a strong foundation in their faith and ethical formation...going out to know the difference between right and wrong and how to make the world a better place. ( Field Data, Respondent 8)

According to the principals such foundation helps students to function effectively wherever they are and in every endeavor in life. Principals believe that freedom is paved through education and providing young people with a solid foundation of education empowers them to have options and choices and gives them that feeling of freedom in their lives.

\section{Conclusion and Recommendations}

There is great value in Catholic education. Principals have a deep understanding of the establishment and mission of IMS. Their involvement in the IMS network fosters their participation and commitment to the accomplishment of the vision and mission of the network. The alignment of principals' vision with the network's vision and mission is necessary for ensuring the effectiveness of the schools and commitment to the network's 
goals. There is a strong Catholic identity in the IMS. There is also a sense of community, and fellow feeling in IMS. IMS is modeled to continue to provide quality Catholic education to the poor and vulnerable in the in lowincome communities across the city of Philadelphia. Mission Schools nurture good and strong moral character in students. Character building or modeling is thus a significant takeaway from the IMS network where students are nurtured and developed academically, morally, and spiritually. The general perception of principals about IMS is that it is a new model of Catholic education, develops students holistically, and gives the poor and vulnerable in society access to quality education at an affordable cost. The operation of schools as a business is however worrying to principals since most of them are not familiar with the business world and its practices. Ensuring sustainability of IMS network may be the greatest challenge stakeholders of the network have to deal with. Therefore, the study recommends that more finances should be obtained, strong Catholic identity should be kept in schools, the network's vision and mission should be revisited regularly, safe, caring, and supportive schools' environment should be created, and teamwork, good relationships and accountability should be encouraged.

\section{References}

Agirdag, O., Driessen, G. \& Merry, M. S. (2017). The Catholic school advantage and common school effect examined: a comparison between Muslim immigrant and native pupils in Flanders. School Effectiveness and School Improvement, Vol. 28 (1), pp. 123-135, DOI:10.1080/09243453.2016.1251469

American Association of School Administrators (2009). Looking back, Looking forward: How the economic downturn continues to impact School Districts. American Association of School Administrators (AASA).

Baccari, S. F. (2018). Preserving Catholic Identity in Catholic Secondary Schools and the Impact on Catholic Identity by Non-Catholic and International Students. Doctoral Dissertation, University of San Francisco. https://repository.usfca.edu/diss/413

Borba, M. (2001). Building moral intelligence. The seven essential virtues that teach kids to do the right thing. San Francisco: Jossey-Bass.

Brisbane Catholic Education (2015). Strengthening Catholic Identity: A Strategic Initiative of Brisbane Catholic Education. Shape Paper, pp. 1-7.

Centre for Catholic School Effectiveness \& Centre for Catholic Education (2012). National standards and benchmarks for effective catholic elementary and secondary schools. Loyola University Chicago.

Cook, T. J. (2008). Catholic identity today: A position paper. Pp. 1-8, Creighton University.

Convey, J. J. (2012). Perceptions of Catholic Identity: Views of Catholic School Administrators and Teachers. Journal of Catholic Education, Vol. 16 (1), pp. 187-214. http://dx.doi.org/10.15365/joce.1601102013

De La Portilla, A. M. (2018). The Closing of Inner-city Catholic Elementary Schools and the Impact on Community: An Ethnographic Instrumental Case Study of Two Neighboring Communities. Doctoral Dissertations, 330, University of the Incarnate Word. https://athenaeum.uiw.edu/uiw etds/330

Fay, J. (2005). Schoolwide discipline plan without the loopholes. USA: Love and Logic Institute, Inc.

Fuller, C., \& Johnson, L. (2014). Tensions Between Catholic Identity and Academic Achievement at an Urban Catholic High School. Journal of Catholic Education, Vol. 17 (2), pp. 95-123. http://dx.doi.org/10.15365/joce.1702062014

Garcia-Huidobro, J. (2017). What Are Catholic Schools Teaching to Make a Difference? A Literature Review of Curriculum Studies in Catholic Schools in the U.S. and the U.K. since 1993. Journal of Catholic Education, Vol. 20 (2), pp. 64-97. http://dx.doi.org/10.15365/joce.2002032017

Gleeson, J., O'Gorman, J., Goldburg, P., \& O'Neill, M. M. (2018). The Characteristics of Catholic Schools: Comparative Perspectives from the USA and Queensland, Australia. Journal of Catholic Education, Vol. 21 (2), pp. 76-106. http://dx.doi.org/10.15365/joce.2102042018

Gleeson, J. (2017). Identity and Curriculum in Catholic Education. Summary Report, Identity and Curriculum in Catholic Education Project, Australian Catholic University, pp. 1-6.

Goldschmidt, E. P. \& Walsh, M. E. (2011). Sustaining Catholic elementary schools. An examination of governance models and funding strategies. Boston College.

Hamilton, S. W. (2008). Who will safe America's Urban Catholic schools? Thomas Fordham Institute.

Hancock, C. L. (2005). Recovering a catholic philosophy of elementary education. USA: Newman House Press.

Hawley, W. D. \& Rollie, D. L. (2007 Eds.). The keys to effective schools: Educational reform as continuous improvement. California: Corwin Press.

Inglis, T. (2007). Catholic Identity in Contemporary Ireland: Belief and Belonging to Tradition. Journal of Contemporary Religion, Vol. 22, No. 2, pp. 205-220. 
Independence Mission Schools (2014). Transforming Young Lives and Communities. Independence Mission Schools 2014 Annual Report.

Independent Auditor's Report (2018). Report on Audit of Financial Statements for the Years ended June 30, 2017 and 2016. Philadelphia Independent Mission Schools D/B/A. O’CONNELL \& COMPANY LLC, pp. 123.

Jacobs, R. M. (1998). U.S. Catholic Schools and the Religious Who Served in Them: Contributions in the 18th and 19th Centuries. Journal of Catholic Education, Vol. 1 (4), pp. 364-383. http://dx.doi.org/10.15365/joce.0104022013

Lewin, K. M. (2007). Improving Access, Equity and Transitions in Education: Creating a Research Agenda. CREATE PATHWAYS TO ACCESS. Research Monograph No 1.

Miserandino, A. (2019). The funding and future of Catholic education in the United States. British Journal of Religious Education, Vol. 41 (1), pp. 105-114, DOI: 10.1080/01416200.2017.1352484

O'Connell, B. D., Harrington, R. D., Monsegur, S. B., Vogtner, K., Burnford, T. W., \& Krebbs, M. J. (2012). Our Schools--Our Hope: Reflections on Catholic Identity from the 2011 Catholic Higher Education Collaborative Conference. Journal of Catholic Education, Vol. 16 (1), pp. 155-186. http://dx.doi.org/10.15365/joce.1601092013

Polka, W., Litchka, P., Mete, R., \& Ayaga, A. (2016). Catholic School Principals' Decision-Making and Problem-Solving Practices During Times of Change and Uncertainty: A North American Analysis. Journal of Catholic Education, 20 (1). http://dx.doi.org/10.15365/joce.2001102016

Schuttloffel, M. M. J. (2012). Catholic Identity: The Heart of Catholic Education. Catholic Education: A Journal of Inquiry and Practice, Vol. 16, No. 1, pp. 148-154.

Slate, J. R., Jones, C. H., Wiesman, K., Alexander, J. \& Saenz, T. (2008). School mission statements and school performance: a mixed research investigation. New Horizons in Education, Vol. 56 (2), pp. 17-27.

Sullins, D. P. (2004). The Difference Catholic Makes: Catholic Faculty and Catholic Identity. Journal for the Scientific Study of Religion, Vol. 43, (1), pp. 83-101.

Tucker, D. (2016). Successful sustainability in a Catholic secondary school. Doctoral Dissertation, Walden Dissertations and Doctoral Studies, Walden University.

United States Conference of Catholic Bishops (2005). Renewing Our Commitment to Catholic Elementary and Secondary Schools in the Third Millennium. Washington DC: United States Conference of Catholic Bishops, Inc.

United States Conference of Catholic Bishops (2013). Catholic Education. Retrieved from www.usccb.org on $18^{\text {th }}$ April 2020.

United States Conference of Catholic Bishops (2016). Catholic School Fact Sheet. Retrieved from www.usccb.org on $18^{\text {th }}$ April 2020.

Van Wormer, K. \& Berns, L. (2004). The impact of priest sexual abuse: Female survivors' narratives. AFFILIA, Vol. 19, No. 1, pp. 53-67.

Bolman, L.G., \& Deal, T. E. (2013). Reframing organizations: Artistry, choice, and leadership (5th ed.). San Francisco, CA: Jossey-Bass.

Bring, F. M. \& Garnett, N. S. (2014). Lost classroom, lost community: Catholic schools' importance in urban America. The University of Chicago Press, Chicago: IL

Coday, D. (2005). Catholic schools grapple with forces of change. National Catholic Reporter, 41(21), 2a-5a. Retrieved from Education Research Complete database.

Cruz, G. (2009). Catholic Schools: How to Fix Parochial Schools' Decline. Online TIME. Retrieved from http://www.time.com/time/nation/article/0,8599,1929589,00.html?artId=1929589? contType=article?chn $=\mathrm{us}$

Meyer, P. (2007). Can Catholic Schools Be Saved? Lacking Nuns and Often Students, a Shrinking System Looks for Answers. Education Next, 7(2), 12-20. Retrieved from ERIC database.

Townsley, M. K. (2014). Financial Strategy for Higher Education: A field guide for Presidents, CEOs, and Boards of Trustees. Raleigh, NC: Lulu Enterprises, Inc. 